\title{
PROTECTIVE EFFECT OF ROTENONE AGAINST LIPOPOLYSACCHARIDE AND D-GALACTOSAMINE-INDUCED HEMATOTOXICITY
}

\author{
SAMRAT RAKSHIT ${ }^{1}$, ANJANI VERMA ${ }^{1}$, SATENDRA KUMAR NIRALA², MONIKA BHADAURIA ${ }^{1 *}$
}

\begin{abstract}
${ }^{1}$ Department of Zoology, Toxicology and Pharmacology Laboratory, Guru Ghasidas University, Bilaspur, Chhattisgarh, India. ${ }^{2}$ Department of Rural Technology and Social Development, Laboratory of Natural Products, Guru Ghasidas University, Bilaspur, Chhattisgarh, India. Email: bhadauria_monika@rediffmail.com
\end{abstract}

Received: 27 May 2019, Revised and Accepted: 24 June 2019

ABSTRACT

Objective: The aim of the present study was to investigate the protective efficacy of rotenone against lipopolysaccharide (LPS) and D-galactosamine (D-GalN)-induced altered hematology.

Methods: Hematotoxicity was induced by coinjection of LPS (50 $\mu \mathrm{g} / \mathrm{kg}$ i.p.) and D-GalN (300 mg/kg i.p.). Rotenone (5, 10 and $20 \mathrm{mg} / \mathrm{kg}$ p.o.) was administered for 6 days as a pre-treatment. Blood was collected through puncturing the retro-orbital sinus to analyze blood parameter. Serum was separated to analyze glucose, triglyceride, and cholesterol.

Results: The present study revealed decreased in red blood cells, platelets, hemoglobin, and hematocrit value while a significant increase in white blood cells, lymphocyte, and monocytes were observed in LPS and D-GalN treated rats. LPS and D-GalN administration significantly decrease glucose level while serum lipid profile (triglycerides and cholesterol level) were increased significantly at 5\% level of significance. LPS and D-GalN-induced altered hematological and serological variables were restored toward control by rotenone pretreatment for 6 days in dose-dependent manner.

Conclusion: It can be said that LPS and D-GalN administration resulted in alteration of various hematological parameters and rotenone at 20 mg/kg dose restored significant alteration toward control due to the presence of antioxidant activity of rotenone.

Keywords: Rotenone, Hematology, Serum lipid, Lipopolysaccharide, D-galactosamine.

(C) 2019 The Authors. Published by Innovare Academic Sciences Pvt Ltd. This is an open access article under the CC BY license (http://creativecommons. org/licenses/by/4. 0/) DOI: http://dx.doi.org/10.22159/ajpcr.2019.v12i8.34324

\section{INTRODUCTION}

Increased oxidative stress alters the balance between pro-oxidants (free radicals) and antioxidants, which is been linked to many human diseases or disorders at present [1]. Free radicals such as reactive oxygen species and reactive nitrogen species are produced in excessive amounts during oxidative stress. Antioxidative defense system (AOS) components are responsible for neutralizing this oxidative stress and protect various cell damages [2]. Erythrocytes contain hemoglobin and polyunsaturated fatty acids, which makes it a suitable target for peroxidation [3]. With the help of AOS components, these cells could protect themselves from oxidative injuries incurred under physiological conditions [4]. Hematology deals with the study of the numbers and morphology of the red cells (erythrocytes), white cells (leukocytes), and the platelets (thrombocytes) and the use of these results in the diagnosis and monitoring of disease [5]. From the diagnosis of a number of diseases to the investigation of the extent of the damage to blood can be done by hematological observation [6]. Physiological status of animals reflects in hematological parameters [7]. As blood circulates almost everything, any toxicity can be detected by the blood [8]. Animals with good hematology showed good performance [9]. Different metabolites and constituents that play an important role in physiological, nutrition, and pathological status of an organism [10] dramatically change with physiological conditions of health [6]. Afolabi 2011 [11] suggested that stress induced by environmental, nutritional, and pathological factors could alter hematological parameters. Lipopolysaccharide (LPS) is one of the main components of the bacterial cell wall and is responsible for generating oxidative stress [12] and inflammation [13]. LPS also activates proinflammatory cytokines, which cause toxicity [14]. D-Galactosamine (D-GalN) is an amino sugar, when metabolized in liver generates a mixture of hexosamines and causes selective uridine triphosphate deficiency, inhibition of ribonucleic acid synthesis, bilirubin conjugation, liver detoxification [15], and disturbances in the biosynthesis of glycoproteins [16]. As a result of depletion of the necessary enzymes involves in energy production from glucose and another substance, a crisis of energy occurs due to D-GalN and its metabolites. D-GalN is also reported to mediate inflammationinduced toxic damage in animals [17]. Rotenone is a member of pea family (Leguminosae), which is very abundant in the roots of plants. From ancient time, rotenone is been used by humankind [18]. Rotenone is harmless to mammals, especially when administered by oral route [19]. Rotenone has a beneficial effect on mammary tumors in Osborne-mendel rats [20]. Therefore, rotenone could be effective against LPS and D-GalN-induced hematotoxicity.

\section{METHODS}

\section{Animals}

Healthy and pathogen free wistar rats. (female, $150 \pm 10 \mathrm{~g}$ ) were housed under standard laboratory conditions $(12 \mathrm{~h}$ periodic light and dark cycle; temperature about $25^{\circ} \pm 2^{\circ} \mathrm{C}$, standard animal diet in palleted forms and water ad libitum) after purchasing from defense research development establishment, Gwalior. The experiment was conducted in accordance with the committee for the purpose of control and supervision of experiments on animal (CPCSEA), Chennai, India. No animals were sacrificed, only blood was collected by puncturing the retroorbital sinus. The experimental protocol was approved by the Institutional Animal Ethics Committee (994/Ere/ Go/06/CPCSEA).

\section{Chemicals}

D-GalN, LPS, and rotenone were obtained from Sigma-Aldrich Co Ltd., USA. 
Dose preparation of rotenone, LPS, and D-GalN for the study of hematotoxicity

Animals were administered with D-GalN (300 mg/2ml/kg) first and then LPS $(50 \mu \mathrm{g} / 2 \mathrm{ml} / \mathrm{kg})$ after $1 \mathrm{~h}$ to induce hematotoxicity. Doses of LPS and D-GalN were prepared separately in $0.9 \%$ normal saline according to Wei et al. (2014) [21] and Jin et al. (2014) [22], respectively. Doses of rotenone $(5,10$, and $20 \mathrm{mg} / \mathrm{kg}$ p.o.) were prepared in $1 \%$ gum acacia.

\section{Experimental design}

Acclimatized animals were divided into six groups of six animals each. Each group of animals received vehicle and different doses of rotenone for 6 days, as explained in Table 1 . On the $6^{\text {th }}$ day, LPS and D-GalN were injected into animals to induce acute blood toxicity. After $18 \mathrm{~h}$ of last treatment, animals were euthanized, on puncturing retro-orbital venous sinus blood samples were collected, and serum was isolated.

\section{Hematological studies}

For hematological indices, blood was collected in heparinized tubes and kept at $4^{\circ} \mathrm{C}$. Blood analyzer (Analytica HEMA 2062+) was employed to determine white blood cell (WBC) count, red blood cell (RBC) count, platelet count, hemoglobulin (HGB), hematocrit (HCT), lymphocyte (LYM), and monocyte (MON) count.

\section{Serological studies}

Serum was separated from blood and used for the determination of glucose, triglyceride, and cholesterol by kit method (The ERBA Chem 5 V3 Germany). Kits were purchased from ERBA Manheim, Germany.

\section{Statistical analysis}

Results are presented as mean \pm SE of six animals used in each group. Statistical significance was determined by one-way analysis of variance $(\mathrm{p} \leq 0.05)$ followed by Tukey's post hoc honestly significant difference (HSD post-hoc test) test to draw a comparison among different treatment groups $(\mathrm{p} \leq 0.05)$ [23].

\section{RESULTS}

\section{Effect of rotenone on hematological variables}

Co-administration of LPS and D-GalN resulted alterations of different hematological variables presented in Table 2. RBCs, HGB, HCT, and platelets content were significantly downed, whereas the number of WBCs including LYMs and MONs were significantly increased (p£0.05).
$10 \mathrm{mg} / \mathrm{kg}$ dose increased RBCs, hemoglobin, platelet, and HCT value only whereas $20 \mathrm{mg} / \mathrm{kg}$ dose significantly altered all the studied variables toward control. Tukey's post hoc HSD test showed that 10 and $20 \mathrm{mg} / \mathrm{kg}$ doses of rotenone showed better therapeutic effect in comparison to $5 \mathrm{mg} / \mathrm{kg}$ dose and reversed hematological alteration toward control. Percent protection analysis showed that $20 \mathrm{mg} / \mathrm{kg}$ dose of rotenone was found better among all the three doses of rotenone and showed over $75 \%$ of the recovery in hemoglobin, HCT, and RBC and WBC counting.

\section{Effect of rotenone on serological parameter}

Table 3 represents the therapeutic efficacy of rotenone pre-treatment on serological variables against LPS and GalN-induced toxic anomalies. LPS and D-GalN administration in rats significantly increase serum lipid profile, whereas glucose becomes abruptly downed. All three doses of rotenone reduced triglyceride, cholesterol while increased glucose toward control. Tukey's post hoc HSD analysis showed that $10 \mathrm{mg} / \mathrm{kg}$ dose was found better than $5 \mathrm{mg} / \mathrm{kg}$ in reducing triglyceride and cholesterol level. The $20 \mathrm{mg} / \mathrm{kg}$ dose of rotenone showed a better protective effect in all parameters except cholesterol. Furthermore, analysis of the recovery pattern suggested that there was no statistically significant difference between control and $20 \mathrm{mg} / \mathrm{kg}$ rotenone treatment group. More than $80 \%$ recovery was observed in almost all the parameters with $20 \mathrm{mg} / \mathrm{kg}$ dose of rotenone.

\section{DISCUSSION}

Hematological investigation often reveals vital information on the body's response to all forms of injury [24]. Blood is responsible for the transportation of each and every molecule to and from the cell. Thus, if something affects the blood; either drug, the pathogen will certainly affect the entire body in terms of health, growth, maintenance, and reproduction $[25,26]$. Thus, a quick check of acute toxicity would be the assessment of hematological evaluation $[27,28]$.

The major hematological components are RBCs, WBCs, mean corpuscular volume, HCT, and hemoglobin concentration. These are valuable in monitoring toxicity in the blood as well as the health status [29]. RBCs carry hemoglobin, which reacts with oxygen to form oxyhemoglobin during respiration [30] and involved in the transport of oxygen and carbon dioxide in the body [8]. Thus, reduction in the RBCs implies a reduction in the level of oxygen that would be carried to the tissues

Table 1: Experimental regimen

\begin{tabular}{llll}
\hline Groups & Treatment & Day 1-6: 10 AM & Day 6: 04 PM \\
\hline 1 & Control & Vehicle only (1\% gum acacia) & Vehicle only (saline) \\
2 & Rotenone per se & Rotenone $(20 \mathrm{mg} / \mathrm{kg})$ & Vehicle only (saline) \\
3 & Experimental control & Vehicle only $(1 \%$ gum acacia) & LPS and GalN \\
4 & Therapy 1 & Rotenone $(5 \mathrm{mg} / \mathrm{kg})$ & LPS and GalN \\
5 & Therapy 2 & Rotenone $(10 \mathrm{mg} / \mathrm{kg})$ & LPS and GalN \\
6 & Therapy 3 & Rotenone $(20 \mathrm{mg} / \mathrm{kg})$ & EPS and Gall \\
\hline
\end{tabular}

LPS: Lipopolysaccharide, GalN: D-Galactosamine

Table 2: Therapeutic effect of rotenone on hematological variables against lipopolysaccharide/d-galactosamine induced hematotoxicity in rats

\begin{tabular}{|c|c|c|c|c|c|c|c|}
\hline Parameter & Control & $\begin{array}{l}\text { Rote per se } \\
\text { Rote } 20 \mathrm{mg} / \mathrm{kg}\end{array}$ & LPS+GalN & $\begin{array}{l}\text { LPS+GalN+Rote } \\
5 \mathrm{mg} / \mathrm{kg}\end{array}$ & $\begin{array}{l}\text { LPS+GalN+Rote } \\
10 \mathrm{mg} / \mathrm{kg}\end{array}$ & $\begin{array}{l}\text { LPS+GalN+Rote } \\
20 \mathrm{mg} / \mathrm{kg}\end{array}$ & $\begin{array}{l}\text { ANOVA } \\
\text { F-value }\end{array}$ \\
\hline Hemoglobin (g/dL) & $15.5 \pm 0.78$ & $15.4 \pm 0.77$ & $10.9 \pm 0.55^{*}$ & $12.8 \pm 0.64^{\alpha} 41 \%$ & $13.9 \pm 0.70^{\Psi} 65 \%$ & $14.6 \pm 0.73^{\Psi} 80 \%$ & 7.56@ \\
\hline Hematocrit (\%) & $44.8 \pm 2.25$ & $43.6 \pm 2.19$ & $35.6 \pm 1.79^{*}$ & $36.5 \pm 1.84^{\alpha} 37 \%$ & $40.7 \pm 2.0569 \%$ & $41.1 \pm 2.07^{\Psi} 79 \%$ & $7.28^{@}$ \\
\hline $\operatorname{RBCs}\left(10^{6} / \mathrm{mm}^{3}\right)$ & $7.83 \pm 0.39$ & $7.86 \pm 0.40$ & $6.11 \pm 0.31^{*}$ & $6.53 \pm 0.33^{\alpha} 30 \%$ & $6.89 \pm 0.35^{\Psi} 56 \%$ & $7.29 \pm 0.37^{\Psi} 75 \%$ & $7.09^{@}$ \\
\hline WBCs $\left(10^{3} / \mathrm{mm}^{3}\right)$ & $11.9 \pm 0.60$ & $11.7 \pm 0.59$ & $17.7 \pm 0.89^{*}$ & $16.5 \pm 0.83^{\alpha} 20 \%$ & $15.9 \pm 0.80^{\alpha} 31 \%$ & $12.7 \pm 0.64^{\Psi, \delta, \Phi} 86 \%$ & $15.1^{@}$ \\
\hline Platelets $\left(10^{3} / \mathrm{mm}^{3}\right)$ & $676 \pm 33.9$ & $682 \pm 34.3$ & $498 \pm 25.0^{*}$ & $517 \pm 25.99^{\alpha} 11 \%$ & $552 \pm 27.7530 \%$ & $607 \pm 30.5^{\Psi} 73 \%$ & 8.65@ \\
\hline Lymphocyte count & $24.3 \pm 1.22$ & $25.6 \pm 1.29$ & $65.5 \pm 3.29 *$ & $63.5 \pm 3.19^{\alpha} 5 \%$ & $54.6 \pm 2.75^{\Psi, \alpha} 26 \%$ & $46.2 \pm 2.32^{\Psi, \alpha, \delta} 46 \%$ & $68.8^{@}$ \\
\hline
\end{tabular}

Data are mean \pm SE of $\mathrm{n}=6$; ${ }^{\circledR}$ Significant at $5 \%$ for ANOVA. ${ }^{*}$ Control versus LPS+D-GalN; ${ }^{\Psi} \mathrm{LPS}+\mathrm{D}-\mathrm{GalN}$ versus LPS+D-GalN+rotenone (5 mg/kg/10 mg/kg/20 mg/kg); ${ }^{\alpha}$ Control versus rotenone $(5 \mathrm{mg} / \mathrm{kg} / 10 \mathrm{mg} / \mathrm{kg} / 20 \mathrm{mg} / \mathrm{kg}) ;{ }^{\phi}$ rotenone $(5 \mathrm{mg} / \mathrm{kg})$ versus rotenone $(10 \mathrm{mg} / \mathrm{kg}) ;{ }^{8}$ rotenone $(5 \mathrm{mg} / \mathrm{kg})$ versus rotenone $(20 \mathrm{mg} / \mathrm{kg}) ;$ and ${ }^{\Phi}$ rotenone $(10 \mathrm{mg} / \mathrm{kg})$ versus rotenone $(20 \mathrm{mg} / \mathrm{kg})$ for Tukey's post hoc HSD analysis at $P \leq 0.05$. LPS: Lipopolysaccharide, D-GalN: D-Galactosamine, Rote: Rotenone, RBCs: Red blood cells, WBCs: White blood cells, SE: Standard error, HSD: Honestly significant difference 
Table 3: Therapeutic effect of rotenone on glucose and serum lipids against lipopolysaccharide/d-galactosamnie induced hematotoxicity

\begin{tabular}{|c|c|c|c|c|c|c|c|}
\hline Parameter & Control & $\begin{array}{l}\text { Rote per se } \\
\text { Rote } 20 \mathrm{mg} / \mathrm{kg}\end{array}$ & LPS+GalN & $\begin{array}{l}\text { LPS+GalN+Rote } \\
5 \mathrm{mg} / \mathrm{kg}\end{array}$ & $\begin{array}{l}\text { LPS+GalN+Rote } \\
10 \mathrm{mg} / \mathrm{kg}\end{array}$ & $\begin{array}{l}\text { LPS+GalN+Rote } \\
20 \mathrm{mg} / \mathrm{kg}\end{array}$ & $\begin{array}{l}\text { ANOVA } \\
\text { F-value }\end{array}$ \\
\hline Glucose (mg/dL) & $114 \pm 5.73$ & $120 \pm 6.03$ & $64.3 \pm 3.23 *$ & $95.0 \pm 4.78^{\Psi} 61 \%$ & $99.0 \pm 4.98^{\Psi} 69 \%$ & $108 \pm 5.43^{\Psi} 87 \%$ & 18.0@ \\
\hline Triglyceride $(\mathrm{mg} / \mathrm{dL})$ & $32.1 \pm 1.61$ & $33.9 \pm 1.70$ & $118 \pm 5.93^{*}$ & $78.8 \pm 3.96^{\Psi, \alpha} 45 \%$ & $55.5 \pm 2.79^{\Psi, \alpha, \phi} 72 \%$ & $44.2 \pm 2.22^{\Psi, \delta} 85 \%$ & 113@ \\
\hline Cholesterol (mg/dL) & $15.3 \pm 0.77$ & $15.8 \pm 0.79$ & $39.6 \pm 1.99 *$ & $32.1 \pm 1.61^{\Psi, \alpha} 30 \%$ & $26.3 \pm 1.32^{\Psi, \alpha, \phi} 54 \%$ & $21.9 \pm 1.10^{\Psi, \alpha, \delta} 72 \%$ & 60.7@ \\
\hline
\end{tabular}

Data are mean \pm SE of $\mathrm{n}=6$; ${ }^{\circledR}$ Significant at $5 \%$ for ANOVA. ${ }^{*}$ Control versus LPS+D-GalN; ${ }^{\psi} \mathrm{LPS}+\mathrm{D}-\mathrm{GalN}$ versus LPS+D-GalN+rotenone (5 mg/kg/10 mg/kg/20 mg/kg);

${ }^{\alpha}$ control versus rotenone $(5 \mathrm{mg} / \mathrm{kg} / 10 \mathrm{mg} / \mathrm{kg} / 20 \mathrm{mg} / \mathrm{kg}) ;{ }^{\phi}$ rotenone $(5 \mathrm{mg} / \mathrm{kg})$ versus rotenone $(10 \mathrm{mg} / \mathrm{kg}) ;{ }^{8}$ rotenone $(5 \mathrm{mg} / \mathrm{kg})$ versus rotenone $(20 \mathrm{mg} / \mathrm{kg}) ; \mathrm{and}$ ${ }^{\Phi}$ rotenone $(10 \mathrm{mg} / \mathrm{kg})$ versus rotenone $(20 \mathrm{mg} / \mathrm{kg})$ for Tukey's post hoc HSD analysis at $P \leq 0.05$. LPS: Lipopolysaccharide, D-GalN: D-Galactosamine, Rote: Rotenone, SE: Standard error, HSD: Honestly significant difference

as well as the level of carbon dioxide returned to the lungs [8,31]. The increase RBC count and hemoglobin content in rotenone administered group may be due to a better iron supply. Rotenone could modulate heme metabolism, thereby minimize the hematotoxicity [32]

Blood platelets are considered to be involved in blood clotting. A prolonged or delayed clot formation during an excessive loss of blood in the case of injury was suggested in low platelet concentration. Packed cell volume or HCT is the percentage (\%) of RBCs in blood [33] that is responsible for the transport of oxygen and absorbs nutrients [8]. Decreased HCT shows poor transportation and thus results in decreased primary and secondary polycythemia. HGB, the iron-containing metalloprotein in the RBCs of all vertebrates facilitates oxygen-transport [34]. This transportation of oxygen by HGB helps the animal harvest energy from the oxidation of ingested food and transport carbon dioxide out of the body to maintain other body functions [8]. According to Peters et al., 2011 [35], HCT and HGB are major indices for evaluating circulatory erythrocytes and are significant in the diagnosis of anemia and also serve as useful indices of the bone marrow capacity to produce RBCs in mammals $[30,36]$.

WBC and its subtypes are responsible for providing protection against infections. They defend the body by deploying phagocytosis and antibodymediated immune response against invasion by foreign organisms. Animals with low WBCs are at high-risk of disease infection, but very high counts implied that animals are generating more antibodies as there is high degree of foreign particles [37]. Infection or antigenic metabolites can also enhance the WBCs along with its differentials to strengthen the immune response. Thus, increased WBC, MONs, and LYMs account for toxic condition in the body [8,38]. Previous study by Chandra et al., 2018, suggested an improvement in hematological parameters leads to better physiological condition and health improvement. It was also suggested that plant secondary metabolites can improve hematological variables toward control after being affected by various toxicity [39]. Rotenone is also a secondary metabolite of various plants; thus, rotenone could follow the same mechanism, thereby improving the hematology.

Reports suggested that significant decrease in blood glucose levels occurs during D-GalN and LPS induction as liver contains a full complement of the necessary enzymes involved in glucose homeostasis and certain toxic substance-induced liver injury may alter the blood glucose level [40]. Alterations in lipid metabolism resulted in increased levels of plasma cholesterol and triglyceride in D-GalN/LPS challenged rats when compared to control. An imbalance between lipid biosynthesis and degradation might explain increased plasma cholesterol and triglyceride [41]. Lipoprotein lipase seems to be partially responsible for the elevated plasma triglyceride levels [42]. Rotenone could inhibit the lipid peroxidation of the cells, thereby improving the cellular homeostasis of various enzymes involved in lipid and carbohydrate metabolism.

\section{CONCLUSION}

From the present investigation, it can be concluded that rotenone at $20 \mathrm{mg} / \mathrm{kg}$ dose potentially reversed hematological alteration occurred due to LPS and D-GalN exposure. Thus, rotenone can be used as a blood protectant or blood purifier.

\section{ACKNOWLEDGMENT}

The authors are grateful to the Department of Zoology, Guru Ghasidas Vishwavidyalaya for providing laboratory facilities and fellowship to Samrat Rakshit and UGC, New Delhi, for partial financial assistance with startup grant [20-1/2012(BSR)/20-12(3/2012] to Dr. Monika Bhadauria.

\section{CONTRIBUTION OF AUTHORS}

Bhadauria M designed the study. Rakshit S carried out the experimental work and drafted the manuscript and was involved in the preparation of the manuscript. Verma A helped to carry out experimental work and data compilation. Nirala SK edited the manuscript. Both Bhadauria $M$ and Nirala SK supervised the entire work. All authors read and approved the final manuscript.

\section{CONFLICTS OF INTEREST}

None of the authors holds any conflicts of interest.

\section{REFERENCES}

1. Srinivasan N, Sathyanarayana D. Antioxidant and hepato protective activity of various extracts of Indigoferabarberi gamble against $\mathrm{d}$-galactosamine induced toxicity in rats. Int $\mathrm{J}$ Pharm Pharm Sci 2014; $10: 111-4$

2. Pamplona R, Costantini D. Molecular and structural antioxidant defenses against oxidative stress in animals. Am J Physiol Regul Integr Comp Physiol 2011;301:R843-63.

3. Krishnamoorthy VK, Rather IA. Protective effects of Emblica officinalis (Amla) on metal-induced lipid peroxidation in human erythrocytes. Pak J Pharm Sci 2016;29:1023-6.

4. Pisoschi AM, Pop A. The role of antioxidants in the chemistry of oxidative stress: A review. Eur J Med Chem 2015;97:55-74.

5. Manual M. Hematologic Reference Ranges. The Merck Veterinary Manual; 2012. Available from: https://www.merckvetmanual.com/ SearchResults?query=hematologic + reference + ranges

6. Togun V, Oseni B, Ogundipe J, Arewa T, Hammed A, Ajonijebu D, et al. Effects of Chronic Lead Administration on the Haematological Parameters of Rabbits-a Preliminary Study. Proceeding of $41^{\text {st }}$ Conference Agriculture Society of Nigeria; 2007. p. 341.

7. Khan TA, Zafar F. Haematological study in response to varying doses of estrogen in broiler chicken. Int J Poult Sci 2005;4:748-51.

8. Olafedehan C, Obun A, Yusuf M, Adewumi O, Oladefedehan A, Awofolaji A, et al. Effects of Residual Cyanide in Processed Cassava Peal Meals on Haematological and Biochemical Indices of Growing Rabbits. Vol. 2. Proceeding of $35^{\text {th }}$ Annual Conference of Nigeria Society for Animals Production; 2010. p. 212.

9. Isaac L, Abah G, Akpan B, Ekaette I. Haematological Properties of Different Breeds and Sexes of Rabbits. Proceeding of $18^{\text {th }}$ Annual Conference Animals Science Association of Nigeria; 2013. p. 24-7.

10. Aderemi F. Effects of replacement of wheat bran with cassava root sieviate supplemented or unsupplemented with enzyme on the haematology and serum biochemistry of pullet chicks. Trop J Anim Sci 2004; 7:147-53.

11. Afolabi KD, Akinsoyinu AO, Abdullah AR, Olajide R, Akinleye SB. Haematological parameters of the Nigerian local grower chickens fed varying dietary levels of palm kernel cake. Poljoprivreda 2011;17:74-8.

12. Kallapura G, Pumford NR, Hernandez-Velasco X, Hargisand B, Tellez G. Mechanisms involved in lipopolysaccharide derived ROS and RNS oxidative stress and septic shock. J Microbiol Res Rev 2014;2:6-11. 
13. Beheshti F, Hosseini M, Taheri Sarvtin M, Kamali A, Anaeigoudari A. Protective effect of aminoguanidine against lipopolysaccharide-induced hepatotoxicity and liver dysfunction in rat. Drug Chem Toxicol 2019. DOI: org/10.1080/01480545.2018.1561712.

14. Ramadan A, Soliman G, Mahmoud SS, Nofal SM, Abdel-Rahman RF. Hepatoprotective and hepatotheraputic effects of propolis against D-galactosamine/lipopolysaccharide-induced liver damage in rats. Int J Pharm Pharm Sci 2015;7:372-8.

15. Galanos C, Freudenberg MA, Reutter W. Galactosamine-induced sensitization to the lethal effects of endotoxin. Proc Natl Acad Sci U S A 1979;76:5939-43.

16. De Oliveira JR, Rosa JL, Ambrosio S, Bartrons R. Effect of galactosamine on hepatic carbohydrate metabolism: Protective role of fructose 1,6-bisphosphate. Hepatology 1992;15:1147-53.

17. Masubuchi Y, Horie T. Endotoxin-mediated disturbance of hepatic cytochrome P450 function and development of endotoxin tolerance in the rat model of dextran sulfate sodium-induced experimental colitis. Drug Metab Dispos 2004;32:437-41.

18. Hien PP, Gortnizka H, Kraemer R. Rotenone-potential and prospect for sustainable agriculture. Omonrice 2003;11:83-92.

19. Ichikawa H, Takagi T, Uchiyama K, Higashihara H, Katada K, Isozaki Y, et al. Rotenone, a mitochondrial electron transport inhibitor, ameliorates ischemia-reperfusion-induced intestinal mucosal damage in rats. Redox Rep 2004;9:313-6.

20. Cunningham ML, Soliman MS, Badr MZ, Matthews HB. Rotenone, an anticarcinogen, inhibits cellular proliferation but not peroxisome proliferation in mouse liver. Cancer Lett 1995;95:93-7.

21. Wei L, Ren F, Zhang X, Wen T, Shi H, Zheng S, et al. Oxidative stress promotes D-galN/LPS-induced acute hepatotoxicity by increasing glycogen synthase kinase $3 \beta$ activity. Inflamm Res 2014;63:485-94.

22. Jin Q, Jiang S, Wu YL, Bai T, Yang Y, Jin X, et al. Hepatoprotective effect of cryptotanshinone from salvia miltiorrhiza in D-galactosamine/ lipopolysaccharide-induced fulminant hepatic failure. Phytomedicine 2014;21:141-7.

23. Snedecor GW, Cochran WG. Statistical Methods. $8^{\text {th }}$ ed. IOWA: State University Press; 1994

24. Ihedioha JI, Okafor C, Ihedioha TE. The haematological profile of the sprague-dawley outbred albino rat in Nsukka, Nigeria. Anim Res Int 2004; $1: 125-32$.

25. Oke U, Herbert U, Ebuzoeme C, Nwachukwu E, editors. Effect of Genotype on the Haematology of Nigerian Local Chickens in a Humid Tropical Environment. Proceeding of $32^{\text {nd }}$ Annual Conference of the Nigeria Society for Animal Production; 2007. p. 18-21.

26. Etim N, Williams ME, Akpabio U, Offiong EE. Haematological parameters and factors affecting their values. Agric Sci 2014;2:37-47.

27. Church JP, Judd JT, Young CW, Kelsay JL, Kim WW. Relationships among dietary constituents and specific serum clinical components of subjects eating self-selected diets. Am J Clin Nutr 1984;40:1338-44.

28. Maxwell MH, Robertson GW, Spence S, McCorquodale CC.
Comparison of haematological values in restricted and ad libitum-fed domestic fowls: White blood cells and thrombocytes. Br Poult Sci 1990;31:399-405.

29. Oyawoye B, Ogunkunle H. Biochemical and Haematological Reference Values in Normal Experimental Animals. New York: Mason; 2004. p. 212-6.

30. Chineke C, Ologun A, Ikeobi C. Haematological parameters in rabbit breeds and crosses in humid tropics. Pak J Biol Sci 2006;9:2102-6.

31. Ugwuene M. Effect of dietary palm kernel meal for maize on the haematological and serum chemistry of broiler turkey. Nig J Anim Sci 2011;13:93-103.

32. Sahu N, Mishra G, Chandra HK, Nirala SK, Bhadauria M. Ameliorative effect of naringenin against antituberculosis drugs induced alterations in hematological parameters of rats. Asian J Pharm Clin Res 2018;11:253-5

33. Purves W, Sadava D, Orians G, Heller H. Life: The Science of Biology. Plants and Animals. Vol 3. United Kingdom: Macmillan; 2003.

34. Sidell BD, O'Brien KM. When bad things happen to good fish: The loss of hemoglobin and myoglobin expression in antarctic icefishes. J Exp Biol 2006;209:1791-802

35. Peters SO, Gunn HH, Imumorin IG, Agaviezor BO, Ikeobi CO. Haematological studies on frizzled and naked neck genotypes of Nigerian native chickens. Trop Anim Health Prod 2011;43:631-8.

36. Awodi S, Ayo J, Atodo A, Dzende T, editors. Some Haematological Parameters and the Erythrocyte Osmotic Fragility in the Laughing Dove (Streptopella senegalensis) and the Village Weaver Bird (Ploceus cucullatus). Vol. 1215. Proceeding of $10^{\text {th }}$ Annual Conference Animal Science Association of Nigeria; 2005. p. 384-7.

37. Soetan K, Akinrinde A, Ajibade T, editors. Preliminary Studies on the Haematological Parameters of Cockerels Fed Raw and Processed Guinea Corn (Sorghum bicolor). Proceeding $38^{\text {th }}$ Annual Conference Nigeria Society Animal Production; 2013. p. 49-52.

38. Kabir M, Akpa G, Nwagu B, Adeyinka I, Bello U, editors. Sexual Dimorphism, Breed and age Characteristics of Rabbits in Zaria, Nigeria. Proceeding of $16^{\text {th }}$ Annual Conference Animal Science Association of Nigeria; 2011. p. 133-7.

39. Chandra HK, Mishra G, Sahu N, Nirala SK, Bhadauria M. Effect of rutin against high-fat diet and alcohol-induced alterations in hematological variables of rats. Asian J Pharm Clin Res 2018;11:186-9.

40. Arai K, Lee K, Berthiaume F, Tompkins RG, Yarmush ML. Intrahepatic amino acid and glucose metabolism in a D-galactosamine-induced rat liver failure model. Hepatology 2001;34:360-71.

41. Hochgraf E, Cogan U, Mokady S. Dietary oxidized linoleic acid enhances liver cholesterol biosynthesis and secretion in rats. J Nutr Biochem 2000;11:176-80.

42. Ray SD, Sorge CL, Raucy JL, Corcoran GB. Early loss of large genomic DNA in vivo with accumulation of ca2+ in the nucleus during acetaminophen-induced liver injury. Toxicol Appl Pharmacol 1990;106:346-51. 